\title{
Street children discourses in russia and cuba
}

- A comparative study aimed at developing preventative measures in public child care

Toril Jenssen, Phd,

Centre for Child and Adolescent Mental Health, North Norway,

University of Troms $\varnothing$, Norway. 
"During Soviet times the slogan "let all be the best for children!" not only possessed the mass consciousness, but was also widely implemented in practice, particularly in the area of social protection" (Koposov 2006:10)

\section{Introduction}

$\mathrm{M}$

y colleague and I came to a centre for rights protection of children and adolescents in a city in Northern Russia. It was a winter day with snow all over. In an open space between the houses, just before the entrance to the centre building, we met two eight or nine-year-old girls, skiing. They were smoking cigarettes. My colleague, who is a Russian, said as a joke: "Don't you know when you smoke a second head will grow on your shoulders?" The answer came right-away: "I don't care!" This little conversation in Russian was our introduction to a series of meetings with different spokespersons working at arenas with influence on child and adolescent welfare in the region.

\section{Positioning and main questions}

We came there, interested in street children, the different ways this phenomenon appears in different cultural contexts, and how a society can prevent children from choosing a life on the streets. UNICEF distinguishes conceptually between two groups of street children. One is children on the streets, meaning children who spend most of their time in the street, but have some relationship with their family, and return home daily, weekly or when they are sick or need help. The other group is children of the streets who have no contact with their family members and live independently (Mickelson 2000). During a dramatic system change Russia has experienced an increasing number of both these groups of children (Holm Hansen, Kristofersen, Myrvold 2003). Cuba and Russia are former commercial, political and cultural partners. After the system change in Russia both countries went into deep poverty. But in Cuba, where the political socialist system remains unchanged since the revolution in 1959, there is said to be no problem of street children. In spite of severe economic problems "the absence of street children has distinguished post-revolutionary Cuba" (Lutjens 2000:55). This contrast suggests that it might be interesting to know more about the Russian situation today, when the former socialist politics can be looked upon differently by people, and then try to compare with the Cuban system. Through transformation processes important issues often appear more clearly. Therefore it might be fruitful in a welfare policy perspective to see these two countries in relation to each other.

I was kindly invited to join in a trip connected to the cooperation programme between Bodø University College and Pomor State University. My colleague is a North Russian psychiatrist who has done studies in this region on adolescents who commit crime, and especially factors related to mental health problems. He arranged all our appointments and functioned as an interpreter in the meetings. I wanted to learn about risk factors in Russian society and about health promoting arrangements for children and adolescents that strengthen their welfare in general. Not only am I interested in how a society can prevent children from starting street life, but also how interventions can offer children of the streets better alternatives.

Our main aim with the visit was to get an impression of how this topic within Russian childcare is articulated, - the way it is mediated by some selected informants centrally positioned in the public welfare regime. We wanted to get an insight into a discourse.

\section{Theoretical approach and background knowledge}

The concept discourse has a lot of definitions, depending on the actual research strategy. For my purpose the following definition covers more or less what I am looking for: "Practices that systematically form the objects of which they speak" (Foucault 1972:49, quoted in Neuman 2001:17). The speech is an act where experiences are conceptualized, and what is real is constructed linguistically, structured in grammar. A discourse may be regarded as spoken and 
written actions. Common to both is that they influence everything that is treated by language. Reality may be understood as socially constructed and materialised in language, verbally or nonverbally through objects or organisations or other arrangements. Discursive processes give rise to social dynamics and establish the premises for possible choices and actions (See Bech Dyrberg et.al. 2001, Philips \& Jørgensen 2002, Foucault 1971). As such, I find the concept 'discourse' a useful tool in trying to understand the structural contexts of childhood from the level of the professional competence among some of those working in fields of practices more or less directly involved with underprivileged groups. It follows that what I present in this article is discursive expressions made by my informants. I emphasize that the content of discourses may differ from data that may be regarded as empirical "facts", documented through other research methods. In discourse analysis one has to be aware of how subject positions are situated and how their situatedness influences their representations of reality. Also the researcher is situated and has to be explicit about this and how it might influence the analysis.

My position in this field of research is coloured by more visits to Cuba than to Russia and a broader contextual knowledge of Cuban civil society and social system than the Russian. In Cuba I have gradually become acquainted with the society and people both through formal and informal situations and relations. My interest in the Cuban political system increased as I experienced the living conditions of the people I met. To Russia I came as a researcher for a formal visit to gather information based on a prepared questionnaire. Memories from one earlier visit to Murmansk, Moscow and St. Petersburg, a study trip with social-work students and colleagues ${ }^{1}$ in the days when the system transformation took place, in January 1991, strengthened my curiosity concerning the present situation. This inequality in background preparations and approach to the data collection may have influenced what I have been looking for and what I have found in the discourses I have studied.

\section{Fieldwork I - Russia}

Starting this exploration I am not looking for power relations or competing discourses or internal contradictions in the field of childcare. I am simply interested in what the discourse or discourses contain and how the people we meet communicate their understandings, opinions and assessments in the conversational situation. I am also interested in how earlier relevant discourses are represented in the actual speech of today: in what way we were presented to an intertextuality concerning child care, and even how the current discourse is interwoven with earlier discourses, in such a way that we can talk about interdiscursivity.

The conversations took place at the offices of professional workers or administrative professional staff. I presented myself and my aims and interests, which had been outlined in phone calls or emails beforehand, when the appointments were made. Then I posed the questions I had prepared, 15 altogether. My colleague translated between English and Russian. We met (1) the leader of one Centre for Rights Protection of Children and Adolescents, (2) the leader for the Department of Social Work and Protection in City Administration, (3) the Ombudsmann for Human Rights in the region, (4) the Police Director for working with criminal children and adolescents, and (5) the leader and cooperation group at the Centre for Temporary Placement of Criminal Youths.

\footnotetext{
${ }^{1}$ From the University College of Finnmark.
} 
Following my prepared questionnaire turned out to be impossible. Obviously, people were immediately engaged and started to give answers very full of information. In situations with several people participating in the conversations, the debate became lively, and while my colleague spoke in his mother tongue with the informants around the table, I could check which of my questions had not been brought into the conversation, in order to confirm that I had obtained the information I needed.

\section{Research material}

The meetings lasted three days. Another minor data collection I have done in Cuba, using fieldwork methods as well as interviews. The value of being present, meeting people face to face, observing the surrounding facilities, sensing the contextual frames of action and listening to the voices representing the reality they experience, can't be strongly enough emphasised.

I have, in addition to the conversational material, studied research literature about orphans, street children and criminal youths in Russia ( Jørn Holm-Hansen et.al. 2003, Stephenson 2001, Koposov 2006, Zykov \& Goncharova 2006), about social work in Cuba (Månsson \& Proveyer 2005) and about street children in Cuba, USA and Brazil (Mickelson 2000). This literature I regard as written texts belonging to the field of study and I will include them in the discourse presentation. Even though they are results of other research and have been through other theoretical treatment, they are part of discourses, and come to the front stage of spoken language during the search for existing knowledge.

What we experienced during the conversations was that the informants to a great degree repeated similar things. I therefore find it reasonable to categorise the material with reference to its main topics.

Using a discourse analytical perspective, I identified 4 different thematic discourses in both countries. I call them:

1. Dominant discourse

2. Competence discourse

3. Gender discourse

4. Alternative discourse

I will present the different discourses from the Russian material, before going into the material from Cuba. To a large degree I refer directly to what informants expressed themselves.

\section{Dominant discourse: Russia}

Very soon we were presented with the concept "Social Orphans". The "problem field' of Russian children and adolescents is represented mainly through this concept. It covers the situation where runaway children either have parents who have lost their parental rights or have deliberately abandoned the children, or they are escaping from homes that are in such a bad state that almost any other way of life seems better. The concept "street children" is not used in the official discourse. One informant said it is not officially acknowledged, but "We have children who walk and walk the whole day; they don't go to school; they sleep on the streets or in empty buildings." At the Centre for Rights Protection of Children and Adolescents they know that many children prefer street life instead of living at centres. They fear being locked in, or put to prison for criminal actions they are involved in, so they also escape from the centres.

The social orphan problem is increasing to an extent that is alarming. This is explained by the high unemployment that came in the northern area when all the region's factories in the paper 
industry were closed after the system change. With this event all the social facilities provided by the state in connection to the work-place disappeared as well, such as free kindergartens and meals. This and the poverty which followed have made it dangerous to have babies, one informant said. Her statement is confirmed by official statistics showing that the birth rate has fallen dramatically.

In Russia there is a tradition of street children, we were told. During the revolution in 1917, the state killed the tsar's family and a lot of people at the same level, but normally they spared the children. These became homeless orphans who started to live in the streets. The number of homeless orphans increased as well after the Second World War, the informant said.

In Soviet times the state was running a special policy towards families and children. "Children are our future" was one of the slogans. They had a law-regulated system with rights to medicine, kindergartens, schools, colleges, institutes and universities, all free. The communist Comsomol system took care of the children and organised different activities in their leisure time. The children were busy with this and didn't have time to be in the streets. Adult unemployment was forbidden by law. Everybody was working and everything was organised by the state. When all social welfare and politically organised social systems were suddenly removed in 1991, together with salaries and hope for the future, how should people manage the parenthood task that they were now left alone with? Many in the northern region had worked in factories and were not well educated, they were unable to protest. And the drinking tradition in Russia was not any longer only a risk factor; it became a serious health problem. Poverty is the most obvious cause of Russian misery. The worst period was from 1985 to 1995, "the Reconstruction Period". The government postponed all kinds of payment to families in this period. People suffered.

A lot of social arrangements were established during the late 1990s to cope with problems that came with the system change, most of them directed to strengthening families. Among such measures are centres providing rooms, food, cleaning, health and social services to social orphans. The main aim of these is to give children family-like institutions of some kind if their own families are not functioning.

The situation is represented in terms of crises, even if the positive side of the change is recognised. For those with high education and for adolescents, the freedom of choice to study and travel is good. But the negative side of the change is bigger. One informant said: "We got the freedom and we got the street children."

\section{The competence discourse: Russia}

Several of our Russian informants pointed to the need for social-work competence. One said it is a problem when there is a lack of intervention in the period when a kid has started street life and has committed a crime. Then there should be a social worker. The lack of professional workers makes this a task for the police, but they don't have the necessary knowledge.

Lack of knowledge is a key expression in the discourse. The factory managers, who, through the change to capitalism, gained the freedom to find their own ways of development, failed because they were not used to this. They had no experience of or competence in economic management within a capitalist world. That was why the factories closed and people lost their jobs.

When Russia started the first "priyut" in 1995 (centre for street kids) they did not know what to provide the children with. They gave them a clean environment and food - the basic needs. Authorities were not ready for this dramatic change of system. Teachers worked at the new temporary centres but they were not qualified, they were pedagogues. There were no psychologists or any other kind of specialists in these first centres. Now all the "priuyts" are 
closed and new centres have been established. These provide help for both children and their families, and since 1995 they educate social workers to deal with the problems. What is at stake is to learn not only to do social work, but learn explicitly how to speak to the children in the streets; how to approach them, what to speak to them about, one informant said. This is true especially with respect to the gangs where the children have the intention of doing criminal acts. Here specialised professionals are needed to work with them, to give them education, a normal family life and a job, to take away the leader of the criminal group, and to prevent the organisation of these criminal gangs, by not giving them reasons to be sent to prison, but by giving them more opportunities.

At this point the discourse touches on a certain Russian problem mentioned by one informant: At the end of the nine years' war with Afghanistan in 1989, thousands of soldiers came home. Those who were not killed themselves had spent their whole youth learning only how to fight and kill. Their competence is in violent actions. Having problems with establishing a normal life, lots of them have instead started criminal groups using their military skills. These groups recruit street children for their criminal activities.

There are plans to create specialist mobile groups to speak with the children as one step to prevent criminality, but the number of families at social risk has not declined. Therefore foster-family systems resembling those to be found in Norway will be developed as well as family-like orphanages.

Taken together, these measures may be regarded as a start in reconstructing the old Soviet ideology concerning state responsibility for helping families. On the other hand, people do not want the state to think for their citizens and control them as before, the informants say. Instead parents need to build competence to think for them selves, to find out what they want and to take responsibility.

\section{A Gender discourse: Russia}

According to another informant, the state has just started to realise the importance of supporting pregnant women. This has to be taken seriously because the country is in a state of severe demographic decline. It is now common to have only one child in a family - or none. In Soviet times pregnant mothers were registered in policlinics and provided with medical checks and support. For a long time now they have received no help or guidance from the state and as a consequence many women refuse to have children or leave their newborn babies at the hospitals. One of our informants reported that mothers are also afraid of sending boys to school because they have to go to the army if they fail to attain good enough school results to enter university.

One major reason for the demographic decline is the high mortality of men unable to cope with the crisis. Life expectancy for Russian men today is 59 years. For women it is 72 . This is the largest gender difference in life expectancy in the world (Koposov 2006). Many Russian men are in bad physical condition with high incidences of strokes, heart attacks and premature death resulting from alcohol consumption. This is related to male psychology, according to one informant. When the man loses his job, he is no longer head of the family. He loses his selfrespect. Women have higher education than men. They take over the leadership in the family and wonder: Why do I need this man?

We met the children living at the centre we visited. We noticed a big difference between the boys' and the girls' section in terms of their cosy and homelike atmosphere. Very little in the boys' rooms was reminiscent of a home. The majority of kids living in the streets are boys and the age is decreasing. The lowest age of street children is now eight-nine years. 
A prolongation to this gender issue is the fact that almost every professional engaged in work with orphans and social orphans is a woman, while the majority of the children in question are boys, and almost every politician on state level is a man. So "there is a lack of masculine examples for children in the child-care sector, and the practical experiences of women working in the sector are little known to the male politicians." (Holm-Hanssen \& al. 2003:105) That means financial decision-makers are lacking knowledge about the practical and often "silent" side of serious social problems with consequences for coming generations.

\section{Alternative discourse: Russia}

Only one of our informants, a police woman, spoke in detail of the necessity to work with the street children themselves, with the gangs who aim to do criminal acts. Obviously this belongs to the area of alternative discourses, not having the same attention as the main one, concentrating on dealing with family parenting abilities in order to "prevent" social orphans.

It is precisely such gangs that form the focus of a research project from the years 1997-2000, exploring "the informal social and economic networks created and used by street children in Moscow to build opportunities for survival and invest into prospective social mobility" (Stephenson 2001). With this research we get a glimpse into a culture with patterns and rules that show street children's strategies for accumulation of social capital aiming at their economic survival. Stephenson has done in-depth fieldwork, observations and interviews with street kids and their helpers. She argues that these children are able to build sophisticated social networks, which serve their immediate survival needs and can also relate to longer-term life plans. In her data there are three different groups of children, the "small bomzhis", the "Arbat system" group and "the gangs", all relating to each other, and all in positions that risk being involved with organised criminality. In her text, organised crime is represented as the strongest social system in Russia today, carrying traditions from Soviet criminal subcultures born in prisons and labour camps. "It can offer both the prospect of employment and career development and also offers an alternative to state social security to its members. It is no wonder that joining organised crime can be attractive to the marginalised youth" (Op. cit.: 541).

In recent times another type of criminal organisation has emerged, that of bandits, who also provide informal enforcement services to businesses (Volkov 1999, ref. in Stephenson 2001). These bandits share notions of mutual assistance, and children who show a preferred behaviour may be offered membership and payments for doing small jobs as a start. Stephenson's informants ( $73 \%$ boys) state that street children from the gangs mostly aspire to go into organised crime when they grow up. In this alternative discourse, among homeless children, such articulations are important and may be predictive of future developments if effective preventative strategies are not developed, implemented and followed up.

\section{Fieldwork II: Cuba}

I started my Cuba visits in 2000 by participating in the Northern Brigade that takes place twice a year with people from all over northern Europe contributing to solidarity work. We were soon introduced to the Cuban Revolution in 1959, and its enduring achievements. The educational and health care systems are strongly protected as well as the political structure. The Revolutionary discourse in Cuba is an important part of the national culture. When the Soviet Union fell, Cuba was left in great difficulties. They lost their main commercial partner and a trustworthy supporter of their political system. They went into the "special period" where new problems followed their efforts to find solutions to the changed economic situation.

Together with some skilled professionals and friends ${ }^{2}$, I twice had the opportunity in resent years to have meetings with several officials from the health and educational sectors. We met

\footnotetext{
${ }^{2}$ From The University College of Bod $\varnothing$ and from The University of Troms $\varnothing$.
} 
people from (1) the sociology department of the University of Havana, (2) the Women's House (3) people from the Ministry of Social Health, (4) A group from the University of Cienfuegos, (5) people from the National Direction of Social Assistance in Havana City, (6) one family doctor, (7) one research psychologist, and (8) one child psychiatrist ${ }^{3}$. What kind of measures are taken in Cuba to prevent children from ending up in the streets? This was one of our questions. It is possible to identify discourses in Cuba similar to those in Russia even if the material is wider and more complex.

\section{Dominant discourse: Cuba}

The street children problem "does not occur very often", we were told. However, there is a problem of some children leaving school and staying away from home during the day. In general however, school discipline is strong enough to prevent children from dropping out. The dominant discourse is therefore not about street children, but about the prevention system that contributes to childhood conditions that make street life unnecessary.

Prevention is built into the health system, which is structured hierarchically with a family doctor and policlinics at the local level, hospitals at the second level and specialised centres at the top. Basic is the family doctor, having all information about the individual's health of approximately 25000 persons in the near area, giving them primary service in cooperation with interdisciplinary teams from the clinic. The health system is related to political institutions on each level of society, with a CDR leader (Committee for the defence of the Revolution) at the neighbourhood level, responsible among other things for selecting delegates to the municipality, the province and the state levels.

In problem cases concerning young people "prevention committees" with representatives from Education, Culture and Health are in charge. They exist in all municipalities and they always represent any minors. The committee members cooperate with other organisations, such as the Women's Organisation, the CDR and the family doctor to obtain information about the child and the family. They also contact the school, the police and social workers. Then together with the staff at policlinics and specialised interdisciplinary teams, they reflect on and analyse the situation and make a plan with specific actions for the child. This is checked and reviewed every month, depending on how grave the problem is. To follow the child and secure continuity in the case of any movement between different support services is regarded as important. The problem is mostly connected to the family, according to several informants, and instead of taking the child out of its family, a tutor will be provided to help them.

The Cuban way of thinking seems to be concerned with the individual in context. The child or youth is a member of a local community and the community is also included in the intervention plan, because problems start here, and it is to this context the child will return after treatment. Sometimes changes have to be effected in the local community surroundings of the child or youth, for example, closing a shop which sells alcohol where the issue is to prevent abuse. Often cultural or artistic activities are included in the plan. The prevention committee has a legal right to intervene in the family and the parents are obliged to sustain the child in a process of changing attitudes or actions. The Cuban organisation is regarded as a net of security.

We were told about the social structure where the different health disciplines work, all focusing more on prevention than on treatment. Prevention starts with a special program for the pregnant mother which continues through the nursery phase until the child starts in kindergarten. The family doctor has extended responsibilities in accordance with an extensively understood

\footnotetext{
${ }^{3}$ Spanish-English translators were Angela Pena, The University of Havana and Pilar Gonzalvo, the Medical University of Cienfuegos.
} 
health concept that for example may include work with groups in a manner similar to social work. The work is often accomplished through some form of community work. At the age of 12 each pupil will go through a test to evaluate level of knowledge and family problems.

The Cuban state provides special schools for those with serious behavioural, intellectual or physical problems. For orphans without relatives and children with dysfunctional families, there are special institutions that are required by law to provide children with necessities and "kindness and affection" in a home-like atmosphere. The concept "social orphan" is not used in the Cuban discourse. "Homeland children" is an expression applied for those living in institutions.

\section{Competence discourse: Cuba}

The Cubans realised after the hardship experienced when the Soviet Union disappeared, that in coping with the new problems, existing social-work competence was not sufficient, being clearly related to the health system and lacking in research competence. At the same time, youth problems also appeared, with groups of youngsters who neither studied nor had work and who frequently spent their days in the streets. It was decided to create a new academic discipline of social work based on sociology and with a strong focus on practice in community work. In this discipline Cuban authorities want to integrate health perspectives and social perspectives as well as developing research competence. The study started in 1998. In addition to this several one-year social-work studies started for youngsters without work or without admission to university studies. After the one year school of social work, the students choose whether they will work practically or start studying a subject of their choice. This is part of a re-construction of the educational system in Cuba initiated to change the tradition of educating an intellectual elite, while poor and marginalised groups became even more marginalised. These schools are described and the idea and reasons behind them in Muños Gutiérrez \& de Urrutia Barroso (2005:70): "The opening of these schools has, without doubt, made it possible to reintegrate more than 6000 young persons into society again, providing them with a profession, a job with a respectable salary, and the possibility to continue studying at university."

We were informed that the idea is also to open the mental health field of study - earlier belonging to the Health ministry and the professions of psychiatry and psychology - towards fields of study consisting of several professions. Step by step the specialist services are directed to the most basic level. A Master's degree study of Social Psychiatry with courses dealing with children and adolescents was mentioned as another educational possibility where a focus on prevention is fundamental. The basic idea in psychiatry education is the connection between physical and psychological aspects of the individual. The new strategy in psychiatry is to pay attention not only to health but to the support of the family.

The competence discourse also included the preventative role of teachers. They are educated to identify misbehaviour and send a child to the Mental Health Centre in the municipality and then to cooperate with specialists there in discussing whether the child needs specialschool training or can continue in ordinary school. Focus is on learning difficulties and how to internalise positive values and avoid anti-social behaviour. At specialist level there is a professional psycho-pedagogue competence in addition to psychologists and psychiatrists, and they cooperate regularly with specialists in art and cultural activities. Interdisciplinary work and prevention are emphasized by all informants.

\section{The Gender discourse: Cuba}

In Cuba much of the preventative work is influenced by a strong women's organisation, Federacion Mujeres Cubanas (FMC). It was one of the organisations that started immediately after the revolution to support the social changes carried out and to act to facilitate social policies. It is represented at all levels of society and is part of all political and professional 
organisations. The women's organisation invites every girl to enter the organisation when they are 14 years old. We were told that most girls accept the invitation, and a big welcome party is held every 8th March at Revolution Place for new members of the women's organisation.

The members of FMC are mediators between practical social, psychological and medical work and the political system. They run 175 Women's Houses (Casas de las Mujeres) nationwide, one in every municipality, where volunteers from different professions work to help women, children and families. From the time of its foundation in 1990 the essential content of this work has been the prevention of social and mental problems and attention to the woman and the family. At the house we visited in Havana, there were courses in conflict resolution and in "Culture for Peace". One hundred and fifty three professionals in medicine, psychology, architecture, technology and many other professions work here. They give individual counselling, do group work with children, youths, housewives or elderly people. They also give courses for groups, for example, on child rearing, how to talk in meetings, personal development, and health problems. They also do outreaching service for children in schools, arranging courses in theatre, dance, flower decoration, health prevention etc. A contact network is developed to help users to get in contact with relevant professionals or helping services.

Services are also provided for men, and the leader of the house refers to an increase in men seeking help. $14,7 \%$ of inquiries now come from men - many more than some years ago. Often they need help to see their children in cases where the woman prevents her partner from taking fatherhood responsibilities. Because a child has the right to a father, they are advised to seek juridical support in such cases. Lonely mothers often choose to do child rearing alone, when her man disappoints her by being unfaithful. If they are not working, they get support from the state. At the women's house, moreover, they can get emotional support.

Most family problems are caused by crowded living conditions, with many generations in the same flat. Resulting partnership problems may require family counselling or therapy. The FMC cannot give any economical help since they are not intended to replace public health services, but they can offer help on the inter-relational level and teach how to live with problems.

The informants expressed concern about the major changes that have occurred in Cuba, such as the spread of prostitution and HIV/AIDS. There are many discussions on these topics. No Cuban woman needs to prostitute herself for a living; it is more a choice to use their body as they like, the leader said. An important aim in the house is to prevent young girls from using abortion as family planning. Here they work with prostitutes to increase their self-esteem and show them how to live without working as prostitutes.

\section{Alternative discourse: Cuba}

There are no homeless street children in Cuba, but the concept "children on the streets" has relevance today, and there is ongoing research on children and youngsters on the streets of Havana (Delgado 2005). We met one of the researchers, a psychologist working at the social work department. Josefina Delgado told us about her project: Children on the streets are represented as a specific challenge demanding immediate resolution. In her project the conditions of the social milieu are regarded as important for the adaptation of behaviour. Communication is said to be the crucial way of establishing relations to others and achieving self-awareness. Human advancement is more dependent on such matters than on material factors. As part of the research an intervention project is carried out in groups of adolescents and young people - mainly boys in urban areas - who had started to become a public nuisance, staying out at nights and drinking too much. They were socially rejected, introspective, and catching no affective links to others. They came from families with economic or housing problems, parents who didn't pay attention; some had parents in prison. These boys are looked upon as the most fragile and vulnerable of the groups at risk, in great danger of becoming offenders. Every step must be taken to prevent them from identifying with antisocial values, 
the researcher said. One of the main aspects of the methodology used in the intervention is "talking, talking, talking" with the youngsters, to gain their confidence and build relations for her work, she told us.

During the project she formed groups and invited them to participate in specially selected games, encouraging them to use their creativity, and get rid of stereotypes. The idea is to help them with communication, listening and understanding that there are alternatives in life. The value in focus was responsibility. Group dynamics were studied. She also involved family and neighbours and relevant people in the community like the CDR leader, a police officer, the Women's Organisation and others through informal conversations. The project was based on the idea that learning rests on affective processes. Paulo Freire's pedagogical perspectives were the main theoretical inspiration.

The result of the project was said to be good, the research was done with interviews, observations and questionnaires. Cognitive, affective and behavioural dimensions were considered. Measuring personality traits was done before and after project activities. Now she is continuing with other problem groups in cooperation with students from the university as group workers and tutors for the youngsters. One idea of hers is to go on using those youngsters from the first experiments who had improved as educators and tutors for coming problem groups of young people, to work with transformations of personality and improvement of behaviour.

In Cienfuegos we were introduced to an intervention project with an interdisciplinary team working twice a week with a group of youths with problems in school or family, with behaviour or health. Some of them had tried suicide. The youths alternated between dancing, theatre, painting and psychotherapy. The main aim was to give them values as human beings, offer communication training and knowledge about themselves, teaching them active techniques for better social behaviour and motivate them for positive attitudes. In practice it is important not to separate mental and behavioural problems, the leaders said. This intervention project was also followed by research and was said to have yielded good results.

\section{Russian and Cuban discourses compared}

The respective discourses display both similarities and differences.

In both these countries risk factors for child welfare are represented as family problems. In Russia, strengthening the family, or giving social orphans family-like conditions in which to live seem to be assessed as the main health-promoting measures. In Cuba, the focus is more on community work and strengthening existing families. The individual is said to be always contextually positioned, and interventions must take this into account. Both dominant discourses acknowledge a need to talk and communicate with the children and youths to stop them from preferring streets or delinquency. To provide youths with work or education is also regarded as important. Cuba seems to have a strong support structure to cope with each individual case when problems occur. Most of the work is achieved through the cooperation between organisational actors, and by interdisciplinary teams. The control system is comprehensive. In Russia state services for families are still poor. Social control systems are said to be destroyed for the benefit of individual freedom.

Russia appears to be rebuilding a new structure as compensation for the one lost as a result of system change, and they need expertise, knowledge and money. In Cuba the discourses seem to be characterised by facing challenges with creativity and inventiveness in finding solutions without money. Both have realised they lack competence in social work. Both have established an academic discipline in this subject and look to learn from the experiences of other countries. In both countries boys form the majority of children with problems. Research on the subject supports this in noting that juvenile delinquency represents an urban male phenomenon primarily (Koposov 2006). 
The professional care-givers are women. In Russia women seem superior to men at the family level, but in Cuba the women's organisation enjoys with more authority and a stronger political position due to the persisting influence of revolutionary ideals.

The new preventative measures in Russia are numerous and seem to be directed towards the factors that lead parents to lose or relinquish their parental rights. This is put forward in HolmHansen \& al. (2003). According to the same report, however, financing the measures seems to be a difficult matter.

In both countries the intertextual aspect is prevailing most often with direct references to earlier discourses like the Revolution and the Special Period in Cuba after the fall of the Soviet Union, and in Russia to Perestroika, the Reconstruction Period, or to "Soviet times". Sometimes these earlier discourses are so interwoven with the discourses of today, that they appear only as culturally specific patterns. One example is when solidarity, as part of the Revolutionary discourse established in the years around 1959, encourages Cuban doctors to do voluntary work in other poor third world countries, despite Cuba itself being a poor country.

In Cuba preventative strategies are said to be built into the whole society. All levels in society are planned and structured around the idea of giving everybody a good life in a socialist system based on equality and solidarity, with no need for extra social work competence. The ideas are part of the Constitution. Basic needs for families are secured through a well developed health system, welfare support, education for all, and a minimum ration supply of food to each individual. But increasing poverty, partly a result of a never ending commercial blockade from the nearest neighbour USA and the breakdown of the Soviet Union and other socialist East European countries, made it necessary to create additional preventative measures. With the one-year social work schools, Cuba seems to have found a solution to two problems in one macro level intervention: More social work competence and fewer youths on the streets. A problem category seems to have been transformed into a helping category.

But all problems are not solved by this. New ones arise quickly from severe poverty, for example sexual abuse of minors by foreign tourists in Cuba. This has resulted in increased penalties for pimping of up to 15 years imprisonment if minors are involved. Still Cuban policies prioritise children's wellbeing and have found solutions for many of those starting a life on the streets, where they risk being exposed to prostitution and drugs. Governmental ideology in this area seems to be supported by research. Russian prostitution is known to be done also by visits to neighbouring countries. Like in Cuba, poverty is the main factor behind the growth in sex trade.

New trends in these two countries may be the recognition of a need to talk to children and youths themselves in order to work preventatively. This is needed not only in practical intervention work, but also in research projects aimed at understanding the social processes at work in both categories of street children, those who have a kind of home, and the homeless ones.

Svetlana Stephenson's research among street children in Moscow indicates the importance of knowing how children themselves interpret and understand their life situation and their choices available. Much of the same is to be found in the research of Josefina Delgado among young people in Havana, but her project is at the same time an intervention for personality development among these youngsters.

\section{Final remarks}

Of course, all the informants we have met are part of the official system in their societies. In Cuba none of them are in opposition to governmental social policy, whereas in Russia the discourse contains also criticism of the authorities' handling of the situation. And of course 
other informants in both countries might have represented reality differently and introduced new topics from other discourses. In that respect the discourses have to be regarded not as objective findings covering all aspects of complex structures and processes. Nevertheless, what these people have related reflects some strong tendencies, which will characterize the welfare debates in their countries, and supposedly also to a certain degree "form the objects of which they speak". The discourse approach has given access to engaged and qualified viewpoints in areas of both practical and theoretical work.

What can we learn from comparing discourses in Russia and Cuba, earlier similar and close cooperation partners within the same ideology, but now separated into completely different social structures and political systems and with such different results when it comes to public child care? Not putting too much thrust to this kind of research data, still I find it remarkable that a poor country like Cuba, in this world of economic injustice and inequality among rich and poor, manages to keep an overall focus on social justice in general and child welfare in particular. And I find it interesting that in Russia, steps seem to be taken to reconstruct and renew former communist ideology concerning social welfare and public care for the benefit of children and adolescents.

This little study I will call a pilot project needing further investigations to obtain a deeper understanding of the processes involved. The findings so far are valuable for reflections about what kind of preventative measures are important to establish in order to prevent children from starting a life on the streets. Maybe we can learn something about integrating preventative ideas in the very basic structures in society, not only of health and education, but in every social area with influence on children and adolescents well-being. To some extent a control system is also a caring system and a net of security. Integrating contextual matters in local surroundings as well as using culture and art activities in preventative interventions among children and youths, are interesting working methods. At least we can reflect about what is similar and what is different when assessing our own welfare situation and public child care. Maybe we can also learn something about showing appreciation of girls through big public celebrations when they enter powerful organisations in charge of gender equality. But perhaps we should also learn to celebrate boys when they do something similar with relevance for gender equality. And maybe we can learn a lot about doing research on children and youths by meeting them face to face in conversations about their life worlds, strategies and dreams. Perhaps through comparative studies of transformation processes and consequences like those in Cuba and Russia we can develop arguments for the importance of protecting welfare systems with certain, but not all-embracing state responsibilities. Maintaining preventative structures for the benefit of children must be superior. They are our future.

Several persons have contributed in different ways to me writing this article. My deep gratitude to: Roman Koposov, Staale Saarheim, Siv Oltedahl, Nina Levin, Amy Holtan, Ian Carson, Ann Mari Skogvoll, Per Henriksen, Angela Pena, Pilar Gonzalvo, Peter Stuart Robinson.

\section{Literature}

Bech Dyrberg, Torben, Dreyer Hansen, Allan \& Torfing, Jacob (red.) Diskursteorien på arbejde. Frederiksberg: Roskilde Universitetsforlag.

Delgado, Josefina Vilariño (2005) Work Experiments With Groups at Risk. In Månsson, S-A \& Proveyer Cervantes, C. (eds.) Social Work in Cuba and Sweden. Achievements and Prospects. Göteborg, Havana: Göteborgs Universitet, Universidad de la Habana.

Foucault, Michel (1972) The Archeology of Knowledge. London: Tavistock.

Foucault, Michel (1999) Diskursens orden. Oslo: Spartacus Forlag. 
Zykov, O.V, Goncharova, L.A. (eds.) (2006) Moscow's Railway Station Children. NAN Foundation's Experience in Working With Homeless Children Living at Moscow Railway Stations. "Working with Your at Risk" series. Issue 10.

Holm-Hansen, Jørn, Kristofersen, Lars B. and Myrvold, Trine Monica (eds.) (2003) Orphans in Russia. Policies for family-like alternatives. Oslo: NIBR-rapport 1.

Koposov, Roman (2006) Adolescents Who Commit Crime: A Study of Factors Associated with Mental Health Problems Among Juvenile Offenders in North-western Russia. Department of Psychology, Faculty of Social Sciences, University of Troms $\varnothing$.

Lutjens, Shery L. (2000) Schooling and "Clean Streets" in Socialist Cuban: Children and the Special Period. In R. A. Mickelson (ed.) Children on the Streets of the Americas. Globaliztion, Homelessness and Education in the United States, Brazil and Cuba. London: Routledge.

Mickelson, Roslyn Arlin (ed.) (2000) Children on the Streets of the Americas. Globalization, Homelessness and Education in the United States, Brazil and Cuba. London: Routledge.

Muños Gutiérrez, Teresa \& Urrutia Barroso, Lourdes (2005) The Development of Social Work in Cuba. Professionalization and its Practice. In Månsson, S-A \& Proveyer Cervantes, C. (eds.) Social Work in Cuba and Sweden. Achievements and Prospects. Göteborg, Havana: Göteborgs Universitet, Universidad de la Habana.

Neumann, Iver B. (2001) Mening, Materialitet, Makt: En innføring i diskursanalyse. Bergen: Fagbokforlaget.

Philips, Louise \& Jørgensen, Marianne W. (2002) Discorse Analysis as Theory and Method. London: SAGE Publications.

Stephenson, Svetlana (2001) Street children in Moscow: using and creating social capital. The Editorial Board of The Sociological Review.

Volkov, V, (1999) Violent Entrepreneurship in Russia. Europe-Asia Studies, 51 (5): 741-754. 